\title{
Perubahan Spasial Rumah Tinggal Tradisional Bali Di Banjar Adat Selat Peken Bangli
}

\author{
I Kadek Sosiawan \\ Magister Arsitektur, Fakultas Teknik, Universitas Udayana \\ deksos@racanadesign.com
}

\begin{abstract}
Spasial menurut Habraken (1978), merupakan wadah aktivitas manusia secara fisik maupun psikis, yang aktivitasnya sangat ditentukan oleh pengetahuan sosial budaya pemiliknya. Hal ini menyiratkan bahwa perubahan kehidupan sosial budaya masyarakat berdampak pada perubahan tatanan spasial. Perkembangan kebudayaan Bali dari kebudayaan agraris menuju kebudayaan industri ditandai dengan perubahan nilai-nilai dan karakteristik kehidupan masyarakat seperti: perubahan kehidupan komunal menjadi individual, sifat-sifat kooperatif menjadi progresif, cara berpikir intuitif menjadi rasional, analitis dan posesif, hidup sederhana menjadi komplek (Robi Sularto, 1974;14). Banjar Adat Selat Peken merupakan banjar tradisional yang awalnya hidup dalam masyarakat agraris. Kemudian berubah kearah hidup non-agraris sejalan dengan perkembangan kebudayaan Bali. Masyarakat kini menekuni profesi-profesi baru dibidang industri dan jasa yang disertai dengan perubahan cara pandang dan cara kehidupan masa kini menyebabkan adanya perubahan spasial rumah tinggal tradisionalnya. Tujuan penelitian ini untuk mengetahui perubahan spasial rumah tinggal tradisional di Banjar Adat Selat Peken menggunakan metode penelitian kualitatif dengan teknik pengumpulan data wawancara dengan tokoh masyarakat, pemilik hunian, untuk mengetahui pola aktivitas masyarakat dan sistem sosial budaya. Observasi lapangan dilakukan dengan mengamati secara langsung tata letak, orientasi, hierarki, dan transparansi rumah tinggal atas terjadinya perubahan tata letak bangunan serta perubahan bangunan untuk menampung kegiatan-kegiatan dengan fungsi baru seperti garase, gudang, warung, dan tempat bekerja. Pemanfaatan bangunan kosong sebagai tempat tinggal bagi kelompok keluarga baru berdampak terciptanya perubahan orientasi tata letak bangunan, transparansi, serta hierarki rumah tinggal tradisional Bali di Banjar Adat Selat Peken.
\end{abstract}

Kata kunci: perubahan, spasial, rumah tinggal, Selat Peken dan Bangli

\section{Spatial Transformation Of Traditional Balinese Residential Houses In Banjar Adat Selat Peken Bangli}

Spatial according to Habraken (1978), is a container of human activity physically and psychologically, its activity is largely determined by the socio-cultural knowledge of its owner. This implies that changes in the socio-cultural life of society have an impact on changes in spatial order. The development of Balinese culture from an agrarian culture to an industrial culture is marked by changes in the values and characteristics of community life such as: changes in communal life into individuals, cooperative traits become progressive, intuitive ways of thinking become rational, analytical and possessive, simple life becomes complex (Robi Sularto, 1974;14). Banjar Adat Selat Peken is a traditional banjar, which was originally an agrarian life of the people. Nowadays it has changed towards non-agrarian life in line with changes in Balinese culture. The community is now pursuing new professions in the fields of industry and services accompanied by changes in perspective and way of life at present causing spatial changes in traditional dwellings. The purpose of this study was to determine the spatial changes of traditional dwelling houses in Banjar Adat Selat Peken using qualitative research methods by collecting data from interviews with community leaders, residential owners, to determine patterns of community activities and socio-cultural systems. Field observations were carried out to directly observe the layout, orientation, hierarchy, and transparency in residential houses. The building layout changes as well as building changes to accommodate activities with new functions such as garages, warehouses, stalls, and workplaces. The use of vacant buildings as dwellings for new family groups has resulted in changes in orientation of building layout, transparency, and hierarchy in traditional Balinese dwellings in Banjar Adat Selat Peken.

Keywords: change, spatial, residential houses, Selat Peken and Bangli

Proses Review : 1 - 20 Mei 2020, Dinyatakan Lolos: 29 Mei 2020 


\section{PENDAHULUAN}

Spasial merupakan unsur pokok dalam pemahaman arsitektur yaitu sebagai wadah aktifitas manusia secara fisik maupun psikis yang mana seluruh aktifitasnya sangat ditentukan oleh pengetahuan sosial budaya pemiliknya (Habraken, 1978:37). Terwujudnya pola perumahan tradisional Bali sebagai lingkungan buatan sangat terkait dengan sikap dan pandangan hidup masyarakat, tidak terlepas dari sendi-sendi agama, adat istiadat, kepercayaan dan sistem religi yang melandasi aspek-aspek kehidupan. Peranan dan pengaruh agama Hindu dalam penataan lingkungan buatan, yaitu terjadinya implikasi agama dengan berbagai kehidupan bermasyarakat (Dwijendra, 2003). Kebudayaan Bali telah berkembang dari kebudayaan agraris menuju kebudayaan industri (Koentjaraningrat, 1987). Masyarakat Bali yang berprofesi di sektor pertanian telah bergeser ke arah sektor jasa dan industri. Penetapan sektor pariwisata sebagai sektor unggulan (leading sector) pertumbuhan ekonomi pada pembangunan lima tahun II (tahun 1974/1979) memperkuat pergeseran perubahan profesi masyarakat dari sektor agraris ke arah profesi non agraris (jasa \& industri) (Suyanto, 2006).

Pergeseran budaya Bali ditandai dengan perubahan nilainilai dan karakteristik kehidupan masyarakat agraris ke industri. Nilai-nilai yang berubah memiliki ciri-ciri sebagai berikut: adanya perubahan kehidupan komunal menjadi individual; sifat-sifat kooperatif menjadi kompetitif; kehidupan kolektif menjadi spesialistis; ciri konservatif menjadi progresif; cara berpikir intuitif menjadi rasional, analitik, dan positif; hidup sederhana menjadi komplek (Robi Sularto, 1974:14).

Banjar Adat Selat Peken merupakan wilayah yang berada di Desa Selat Kecamatan Susut, Kabupaten Bangli. Secara geografis di sisi Barat adalah Banjar Adat Selat Tengah, di sisi Timur adalah Desa Adat Susut, di sisi Utara adalah Desa Adat Nyuhan, dan di sisi Selatan adalah Desa Adat Petak yang merupakan wilayah Kabupaten Gianyar. Banjar Adat Selat Peken merupakan banjar tradisional yang awalnya memiliki kehidupan masyarakat agraris dengan ketersediaan lahan pertanian dan perkebunan. Kehidupan masyarakat Banjar Adat Selat Peken pada awalnya merupakan masyarakat agraris dengan hampir semua penduduknya berprofesi sebagai petani, namun sejalan dengan perkembangan kebudayaan Bali saat ini profesi masyarakat Banjar Adat Selat Peken telah bergeser tidak lagi hanya sebagai petani namun berkembang ke profesi-profesi non agraris lainnya yaitu jasa dan industri.

Perubahan kehidupan dari masyarakat agraris menjadi masyarakat industri yang ditandai dengan perubahan profesi masyarakat mengakibatkan perubahan cara pandang serta aktifitas masyarakat. Kehidupan masyarakat komunal bergeser menjadi individual. Hal ini mengakibatkan ruang hunian tidak lagi mampu menunjang perubahan aktifitas serta tuntutan penghuninya. Kompleksitas aktifitas yang tinggi, serta pesatnya peningkatan pertambahan penduduk juga merupakan faktor yang mengakibatkan perubahan spasial pada rumah tinggal akibat meningkatnya kebutuhan akan ruang dan ruangan.

\section{TINJAUAN TEORI}

Perubahan merupakan pola penularan atau status yang stabil kepada satu pola kelakuan dan status stabil yang lainnya. Sejalan dengan hal ini, perubahan atau transformasi dapat diartikan sebagai suatu hal atau keadaan yang berubah atau beralih dari keadaan satu ke keadaan lainnya (Poerwadarminta, 1989). Perubahan dalam kehidupan masyarakat tersebut merupakan fenomena sosial yang wajar, oleh karena setiap manusia mempunyai kepentingan yang tidak terbatas. Perubahan-perubahan akan nampak setelah tatanan sosial dan kehidupan masyarakat yang lama dapat dibandingkan dengan tatanan dan kehidupan masyarakat yang baru (Abdulsyani, 2007). Elemen pembentuk ruang/ spasial dapat dikatakan berubah apabila terjadi: (1) penambahan (additional) yaitu penambahan suatu elemen dalam suatu tapak sehingga terjadi perubahan; (2) pengurangan (elimination) yaitu pengurangan suatu elemen dalam suatu tapak sehingga terjadi perubahan; (3) pergeseran/perpindahan (movement) yaitu adanya perpindahan/pergeseran ruang pada suatu tapak (Habraken, 1982). Menurut Rapoport (1983), perubahan elemen dapat dikelompokkan menjadi: (1) elemen inti (core element) yang sulit berubah, bersifat tetap atau tidak dapat dihilangkan dan menjadi identitas pemilik arsitektur tersebut; (2) elemen pinggiran merupakan bagian yang tidak terlalu penting dan mudah berubah; (3) elemen tambahan (new element) yaitu elemen tambahan yang menjadi bagian baru.

Spasial merupakan aspek meruang dalam pengertian bahwa ruang dipahami bukan semata-mata bersifat geometris, bebas nilai atau ruang dalam pengertian ruang euclide, melainkan ruang dalam kaitannya dengan nilai-nilai sosial dan nilai-nilai budaya. Ruang memiliki makna, nilai, bersifat heterogen, mempunyai pengertian metatorik (bukan matematik), dan erat kaitannya dengan aspek-aspek sosial dan kultural (Fathony, Mulyadi, Sukowiyono; 2012).

Spasial merupakan wadah aktifitas manusia baik fisik maupun psikis. Seluruh aktivitas manusia sangat ditentukan oleh pengetahuan sosial budaya yang dimilikinya. Sistem spasial merupakan salah satu komponen pembentuk arsitektur sekaligus penghuni dalam rangka mendiami suatu spasial arsitektur. Dua komponen yang lain adalah sistem fisik dan sistem stilistik (Habraken, 1978:37). Menurut Ronald (2005), bahwa unsur-unsur spasial pada hunian terdiri dari: arah (orientation), letak (setting), tingkatan (hierarchy), keterbukaan (transparency), dan besaran ruang (size). 


\section{METODE PENELITIAN}

Penelitian ini menerapkan metode penelitian kualitatif dengan pendekatan historis. Penelitian dengan pendekatan historis bertujuan untuk membuat rekonstruksi masa lampau secara sistematis dan objektif (Suryabrata, 2002). Penilitian ini diawali dengan merekonstruksi kondisi spasial rumah tinggal di Banjar Adat Selat Peken pada saat kehidupan masyarakat agraris atau sebagian besar profesi masyarakat adalah petani. Gambaran spasial disusun berdasarkan informasi yang diperoleh melalui wawancara dengan narasumber seperti: pemilik, Kelihan Adat, dan tokoh masyarakat yang ditentukan dengan teknik purposive sampling.

Data tersebut selanjutnya dikomparasikan dengan gambaran kondisi spasial rumah tinggal saat ini yang menghasilkan gambaran perubahan spasial rumah tinggal yang terjadi di Banjar Adat Selat Peken. Temuan fenomena lapangan selanjutnya didialogkan dengan berbagai macam teori untuk menghasilkan temuan akhir penelitian, selanjutnya hasil kajian dirangkum dalam bentuk simpulan.

\section{Lokasi Penelitian}

Lokasi penelitian yaitu di Banjar Adat Selat Peken, Desa Selat, Kecamatan Susut, Kabupaten Bangli. Sebelah utara adalah Desa Adat Nyuhan, sebelah Timur adalah Desa Adat Susut, sebelah Barat adalah Banjar Adat Selat Tengah, dan sebelah Selatan adalah Banjar Adat Petak Kaja.

\section{PEMBAHASAN}

\section{Perubahan Spasial Rumah Tinggal}

Bagi masyarakat Banjar Adat Selat Peken, rumah bukan saja sebagai tempat tinggal, juga merupakan ruang berdeviasi budaya yang terkait dengan tatanan adat yang telah terjadi dalam kurun waktu yang sangat lama. Aktifitas budaya yang dijiwai Agama Hindu terjadi pada rumah tinggal dengan intensitas waktu yang cukup tinggi. Ritual keagamaan berlangsung di rumah terkait dengan tahapan-tahapan hidup orang Bali yang tertuang dalam sastra Agama Hindu yang dikenal dengan ajaran Catur Asrama yaitu Brahmacari (masa belajar), Grhastha (berkeluarga), Wanaprasta (hidup spiritual) dan Sanyasa/Bhiksu$k a$ (meninggalkan kehidupan duniawi). Kegiatan ritual keagamaan dilaksanakan pada setiap proses dalam setiap tahap fase kehidupan seperti kelahiran bayi, telu bulanan, otonan, menek bajang, menikah, potong gigi dan ngaben. Ruang-ruang yang mengakomodir upacara ritual keagamaan tersebut seperti natah, lebuh, bale dangin dan sanggah.

Rumah tinggal di Banjar Adat Selat Peken terbangun di atas tanah desa atau tanah pekarangan desa dengan jumlah $150 \mathrm{karang} /$ bidang tanah. Rata-rata luas satu pekarangan sebagai satu unit rumah tinggal berkisar antara 6 are sampai 30 are. Pemanfaatan tanah desa sebagai rumah tinggal

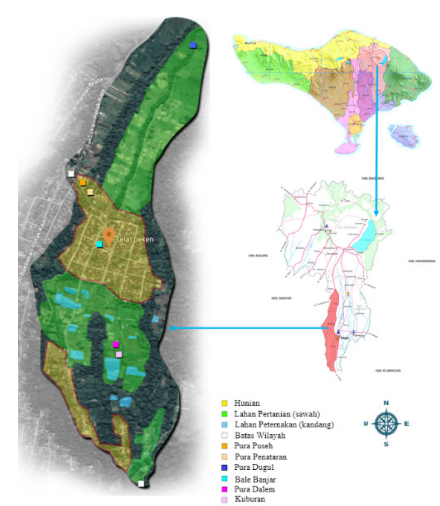

Gambar 1. Peta Banjar Adat Selat Peken Bangli (Sumber: diolah dari www.googlemaps.com)

terkait dengan tatanan adat yang terbangun dari jaman dahulu dengan mempertimbangkan hak dan kewajiban warga masyarakat.

Berdasarkan observasi lapangan sebanyak 23 unit rumah tinggal digunakan sebagai sample dalam meneliti perubahan spasial pada rumah tinggal. Sample dikelompokkan menjadi empat kategori berdasarkan posisi rumah dengan jalan.

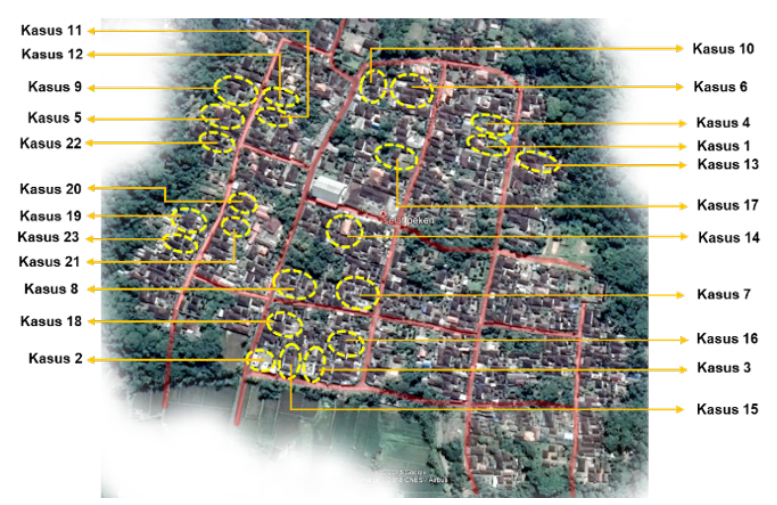

Gambar 2. Peta lokasi rumah yang digunakan sebagai sample (Sumber: diolah dari www.googlemaps.com)

Tabel 1. Tabel kelompok posisi rumah tinggal dengan jalan

\begin{tabular}{lll}
\hline No. & Posisi Rumah Tinggal dengan Jalan & Jumlah \\
\hline 1. & Rumah yang berada pada sisi Utara jalan & 3 unit \\
\hline 2. & Rumah yang berada pada sisi Selatan jalan & 1 unit \\
\hline 3. & Rumah yang berada pada sisi Barat jalan & 11 unit \\
\hline 4. & Rumah yang berada pada sisi Timur jalan & 8 unit \\
\hline
\end{tabular}

Perubahan spasial rumah tinggal dilihat dari unsur-unsur spasial yaitu setting (tata letak), orientasi, hirarki, dan transparansi.

\section{Letak (setting)}

Letak adalah posisi keberadaan seluruh komponen pembentuk ruang (Ronald, 2005:136). Berdasarkan empat kelompok posisi rumah tinggal dengan jalan yang digunakan sebagai sample, akan dibahas satu sample pada 
masing-masing kelompok.

1. Rumah yang berada pada sisi Utara jalan

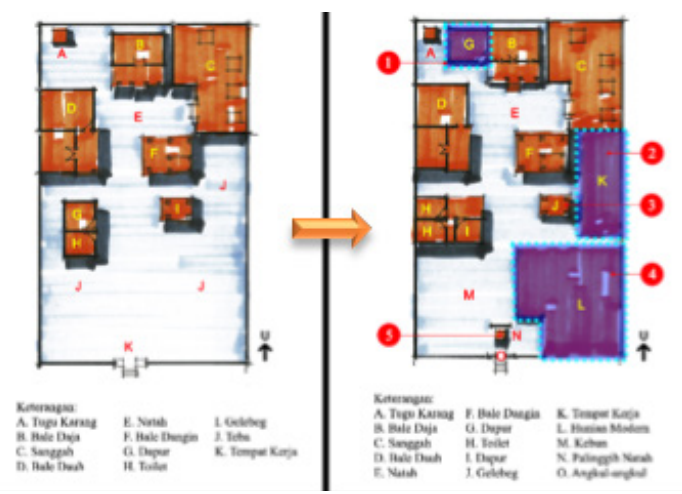

Gambar 3. Tata letak rumah tinggal sebelum dan sesudah adanya perubahan pada rumah Bapak Wayan Nomer (Sumber: Observasi lapangan)

2. Rumah yang berada pada sisi Selatan jalan

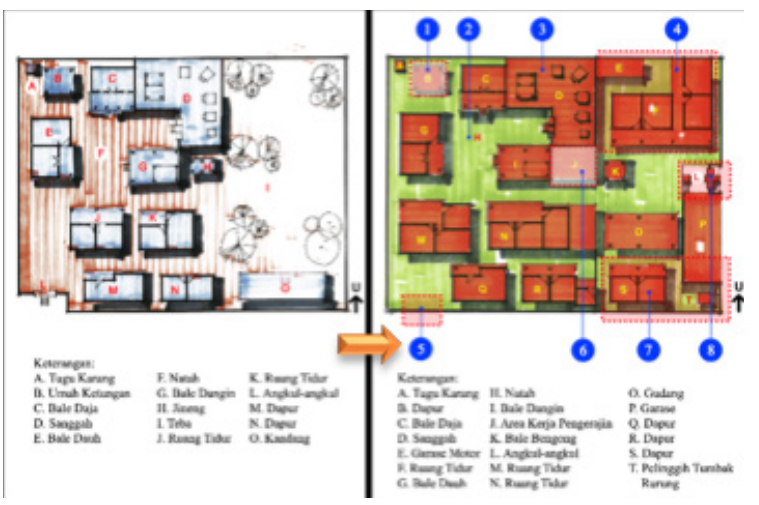

Gambar 4. Tata letak rumah tinggal sebelum dan sesudah adanya perubahan pada rumah Bapak Nengah Dana

(Sumber: Observasi lapangan)

3. Rumah yang berada pada sisi Barat jalan

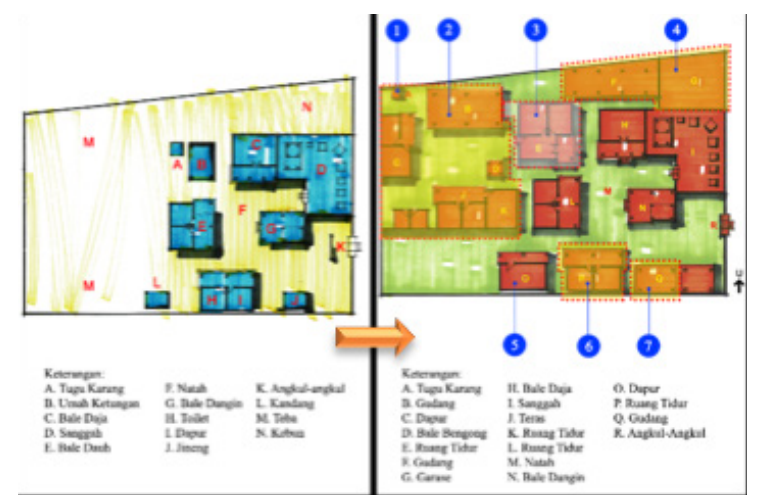

Gambar 5. Tata letak rumah tinggal sebelum dan sesudah adanya perubahan pada rumah Bapak Nengah Ariyoga

(Sumber: Observasi lapangan)
4. Rumah yang berada pada sisi Timur jalan

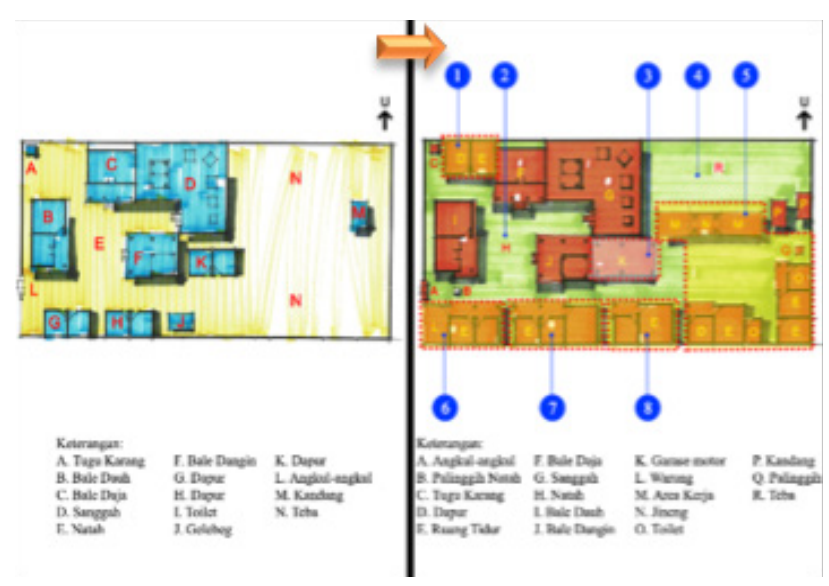

Gambar 6. Tata letak rumah tinggal sebelum dan sesudah adanya perubahan pada rumah Bapak Nyoman Sera Sumber: Observasi lapangan

Penambahan civitas pada rumah tinggal berdampak pada adanya penambahan aktifitas sehingga menuntut atau memerlukan ruang-ruang dalam menampung perubahan tersebut. Penambahan bangunan sebagai penunjang aktifitas penghuni yang bertambah berupa bangunan hunian, dapur, gudang, toilet dan tempat kerja bagi masyarakat yang berprofesi sebagai perajin. Penambahan jumlah anggota keluarga yang terus meningkat menyebabkan rumah tidak lagi menampung semua aktivitas penghuninya. Diperlukan memperluas area rumah tinggal dengan memanfaatkan area kosong yang masih tersedia. Teba menjadi alternatif pengembangan rumah hunian.

Teba beralih fungsi tidak lagi sebagai tempat membuang sampah atau buang air namun sudah menjadi hunian-hunian baru sebagai dampak dari perubahan rumah tinggal. Umah Ketungan sebagai tempat mengolah padi hasil panen di sawah dan jineng sebagai tempat penyimpanan hasil panen kini telah berubah menjadi fungsi-fungsi baru. Umah Ketungan telah hilang digantikan dengan bangunan hunian, dapur, atau gudang. Sebagai dampak dari perubahan kebiasaan masyarakat saat ini yang tidak lagi mengolah padi menjadi beras atau menyimpannya di lumbung tetapi hasil panen dijual, uangnya ditabung atau dibelikan kebutuhan hidup.

Natah sebagai pusat aktifitas ritual keagamaan dan sekaligus sebagai ruang interaksi antar anggota keluarga, bahkan menampung aktifitas-aktifitas baru seperti menjemur pakaian, tempat parkir sepeda motor akibat dari hilangnya ruang-ruang servis seperti teba menjadi area hunian baru. Perubahan spasial pada area profan yang begitu masif tidak terlalu signifikan terjadi pada area sakral.

Bangunan-bangunan seperti bale adat yang terkait dengan upacara ritual keagamaan masih terjaga dengan baik. Bale Daja dan Bale Dangin berfungsi sebagai tempat penting 
bagi masyarakat dalam melaksanakan upacara keagamaan seperti potong gigi, pernikahan, dan ngaben. Dalam keseharian Bale Dangin juga dimanfaatkan untuk melaksanakan kegiatan menunjang aktifitas sesuai dengan profesi masyarakat saat ini, seperti tempat menyimpan barang dagangan atau menyimpan alat-alat untuk keperluan keseharian.

\section{Orientasi}

Orientasi adalah arah perhatian utama suatu perasaan baik seseorang maupun sekelompok terhadap tanda-tanda tertentu dalam lingkungan kehidupannya. Pada umumnya status tanda-tanda tersebut adalah tetap, misalnya: arah peredaran matahari Timur-Barat, arah mata angin utara-selatan, sungai/air, lapangan terbuka, bangunan gedung, menara/tugu (Ronald, 2005:75).

Konsep Tri Angga selain dilihat dari aspek vertikal, juga dapat dilihat secara horizontal. Penataan bangunan berdasarkan konsep ini dibagi menjadi tiga yaitu: utama, madya dan nista. Bangunan yang terletak di sebelah Kaja merupakan bangunan yang memiliki kedudukan lebih tinggi seperti merajan atau tempat suci (parahyangan), bangunan yang terletak di tengah merupakan tempat hunian (pawongan), sedangkan bangunan yang terletak di sisi Kelod adalah bangunan fungsi kotor (palemahan) seperti kandang hewan atau pemesuan yang berfungsi sebagai pintu masuk pekarangan (Budi Harjo, 1986).

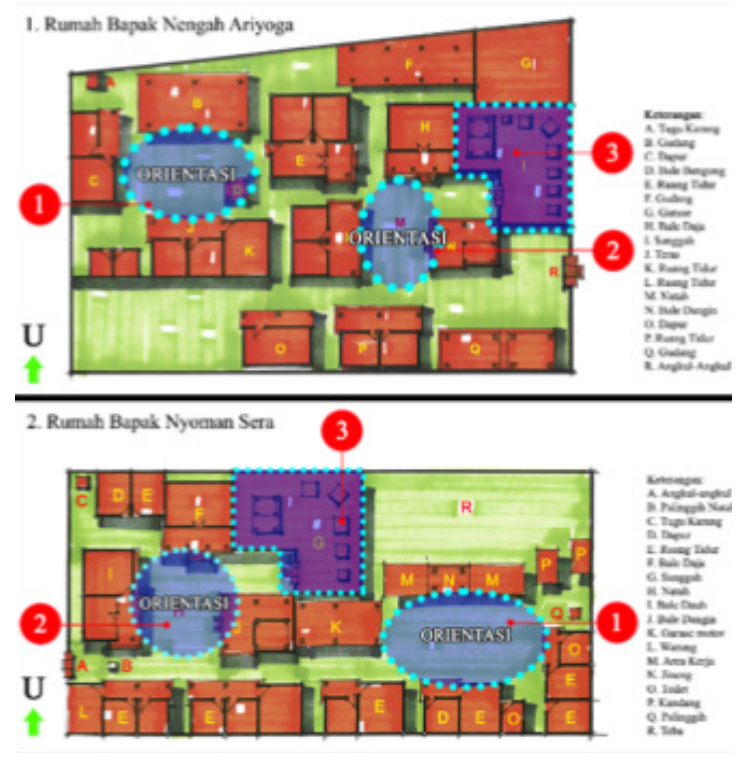

Gambar 7. Natah sebagai orientasi rumah tradisional Bali (Sumber: Observasi lapangan)

1. Pengembangan lahan kosong sebagai rumah tinggal bagi kelompok keluarga baru berdampak terciptanya orientasi baru terkait tata letak bangunan.

2. Natah sebagai orientasi dan pusat aktifitas budaya dan keagamaan masyarakat.

3. Arah kaja merupakan bangunan yang memiliki kedudukan lebih tinggi seperti merajan atau tempat suci (parahyangan), namun karena keterbatasan lah- an area ini dimanfaatkan sebagai hunian dan gudang.

Berdasarkan sudut pandang konsepsi tersebut, maka rumah tradisional di Banjar Adat Selat Peken berorientasi ke arah Kaja Kangin dengan tatanan susunan area utama, madya dan nista. Kehidupan masyarakat kini mengalami perubahan, jumlah penghuni meningkat, keluarga pokok yang menjadi penghuni rumah telah berkembang menjadi keluarga besar, ruang-ruang kosong telah berubah menjadi bangunan-bangunan fungsi hunian untuk menampung perubahan anggota keluarga. Aktifitas-aktifitas penghuni menuntut privasi yang lebih tinggi akibat munculnya kelompok-kelompok anggota keluarga baru. Hal ini mengakibatkan adanya perubahan orientasi tata bangunan. Kepala keluarga beserta anggota keluarga hidup berkelompok dan terpisah dengan anggota keluarga yang lain walaupun masih dalam satu pekarangan keluarga besar.

\section{Transparansi}

Pengertian keterbukaan (transparency) pada lingkungan spasial bersifat relatif, secara umum bernuansa tertutup atau terbatas (Ronald, 2005:138). Suatu batas wilayah yang menjadi kepemilikan dan kekuasaan seseorang atau sekelompok orang yang di dalamnya terdapat privasi dan pertahanan dari intervensi pihak lain disebut teritori (territory).

Penambahan jumlah penghuni pada rumah tradisional Bali di Banjar Adat Selat Peken pada awalnya hanya dihuni satu atau dua kepala keluarga kemudian saat ini berkembang menjadi beberapa kepala keluarga. Adanya tuntutan akan kenyamanan privasi mengakibatkan adanya pengelompokkan hunian sesuai jumlah kepala keluarga.

Kelompok-kelompok hunian pada satu pekarangan terbangun di luar area rumah adat (bale Daja, bale Dangin, bale Dauh, Sanggah) antara satu kelompok dengan kelompok lain hanya dibatasi ruang kosong. Walaupun ada pengelompokan hunian untuk masing-masing anggota keluarga sebagai usaha menghindari perselisihan dan memenuhi privasi, namun semua anggota keluarga masih mempertahankan ruang-ruang komunal bale adat dan ruang-ruang budaya sebagai ruang berasama untuk melaksanakan upacara ritual keagamaan sekaligus sebagai ruang interaksi antar sesama anggota keluarga maupun antar penghuni rumah dengan tamu.

Natah sebagai pusat kegiatan budaya sekaligus sebagai ruang bersama yang dimanfaatkan semua anggota keluarga untuk aktifitas upacara keagamaan sekaligus kegiatan adat. Hal ini memberikan gambaran bahwa ada beberapa pengelompokan ruangan pada satu pekarangan rumah tinggal yaitu kelompok ruang bersama, merupakan kelompok ruang-ruang sebagai penunjang pemenuhan aktifitas-aktifitas komunal baik kegiatan adat maupun kegiatan keagamaan dimana ruang bersama juga berfungsi sebagai ruang interaksi antar sesama anggota keluarga penghuni 
rumah, sedangkan kelompok hunian untuk masing-masing kepala keluarga yang terdiri dari beberapa anggota keluarga merupakan ruang-ruang untuk menunjang aktifitas keseharian anggota keluarga serta guna memenuhi tuntutan akan privasi kenyamanan, masing-masing anggota keluarga antara satu kelompok dengan kelompok lainnya membentuk satu teritori yang hanya dibatasi ruang kosong.

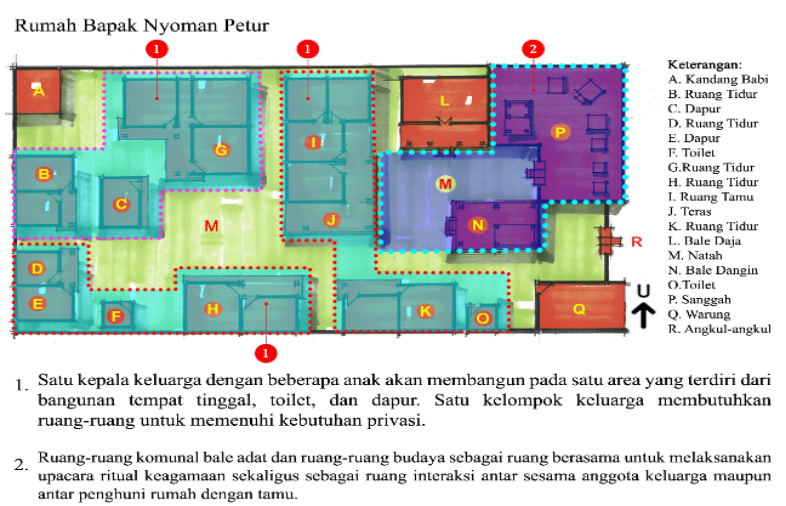

Gambar 8. Kelompok-kelompok ruang privasi dengan ruang bersama. (Sumber: Observasi lapangan)

\section{Hierarki}

Tingkatan berdasarkan arti kata adalah lapisan, kedudukan, atau nilai. Hierarki adalah urutan tingkatan. Dalam pola spasial, tingkatan atau hirarki merupakan tatanan nilai yang membentuk kategori ruang, meliputi jenis ruang (sakral-profane) dan sifat ruang (publik, semi private, private).

Tingkatan berdasarkan arti kata adalah lapisan, kedudukan, atau nilai. Hierarki adalah urutan tingkatan. Dalam pola spasial, tingkatan atau hirarki merupakan tatanan nilai yang membentuk kategori ruang, meliputi jenis ruang (sakral profane) dan sifat ruang (publik, semi private, private).

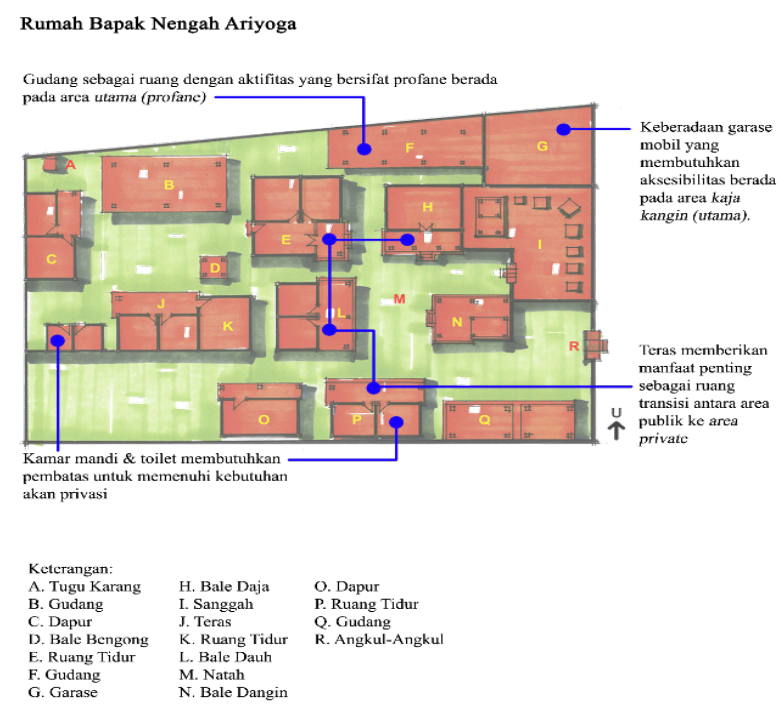

Gambar 9. Salah satu kasus area nista terletak pada area-area yang bersifat utama. (Sumber: Observasi lapangan)
Bangunan-bangunan dengan fungsi-fungsi baru seperti adanya toilet, garase, gudang, dan tempat kerja (pengerajin). Dilihat dari aktifitas fungsi-fungsi ini dikategorikan sebagai aktifitas profane, walaupun tidak pada semua kasus. Fungsi-fungsi ini banyak berada pada tempat Kaja Kangin atau utama. Gudang dan garase mobil berada di sebelah Utara tempat suci/sanggah. Toilet memerlukan ruang yang mampu menunjang privasi penggunanya, sedangkan garase lebih mengedepankan kemudahan aksesibilitas. Fungsi-fungsi baru yang dalam tatanan tradisional merupakan area nista kini terletak pada area-area yang bersifat utama. Hal ini menggambarkan bahwa rumah tinggal kini tidak hanya ditata berdasarkan pada tata nilai tradisional namun juga mengakomodir pertimbangan-pertimbangan modern yang lebih mengedepankan nilai efektifitas, efisiensi, dan aksesibilitas.

\section{SIMPULAN}

Penambahan civitas pada rumah tinggal mengakibatkan adanya perubahan pola aktifitas penghuninya yang berdampak pada meningkatnya kebutuhan ruang. Untuk memenuhi kebutuhan tersebut penambahan bangunan rumah tinggal tidak bisa dihindari dengan memanfaatkan lahan-lahan kosong.

Teba yang awalnya merupakan area servis kini telah berubah menjadi hunian-hunian baru. Umah Ketungan dan Jineng yang pada awalnya merupakan tempat mengolah serta menyimpan padi kini tidak lagi mampu bertahan, tergantikan menjadi fungsi-fungsi untuk mengakomodir kebutuhan masa kini seperti dapur, gudang, dan tempat tidur. Natah sebagai pusat aktifitas ritual keagamaan sekaligus ruang komunal sebagai media interaksi, kini mengakomodir fungsi-fungsi baru.

Pemanfaatan lahan kosong sebagai rumah tinggal bagi anggota kelompok keluarga baru berdampak terciptanya orientasi baru terkait tata letak bangunan, sehingga natah bukan merupakan satu-satunya orientasi.

Terjadi pengelompokkan rumah yang dihuni masing-masing kelompok kecil keluarga sehingga terciptanya teritori pada masing-masing kelompok rumah tinggal yang hanya dibatasi ruang kosong (gang).

Rumah tinggal kini dibangun tidak saja mengacu pada tata nilai tradisional dengan masih memperhatikan tingkatan nilai sakral dan profan serta tata nilai utama, madia, dan nista, namun juga mengakomodir pertimbangan-pertimbangan modern yang mengedepankan efektifitas, efesiensi, dan aksesibilitas. 


\section{DAFTAR PUSTAKA}

Abdulsyani. 2007. Sosiologi Skematika, Teori, dan Terapan. Jakarta: PT Bumi Aksara.

Budihardjo, E. 1986. Architecture conservation in Bali. Yogyakarta: Gajah Mada University Press.

Dwijendra, N. K. A. 2003. Perumahan dan Permukiman Tradisional Bali. Fakultas Teknik Program Studi Arsitektur, Universitas Udayana, Bali.

Fathony, Mulyadi, Sukowiyono. 2012. Rumah dan Permukiman Tradisional yang Ramah Lingkungan. ITN Malang.

Habraken, N. John. 1978. General Principles A Bout the Way Built Environment Exist. Massachusetts.

Koentjaraningrat. 1987. Sejarah Teori Antropologi I. Jakarta: UI Press.

Poerwadarminta, W.J.S. 1990. Kamus Besar Bahasa Indonesia. Balai Pustaka, Jakarta.

Rapoport, Amos. 1969. House Form and Culture. Englewood Cliffs, New York: Prentice Hall. Inc

Rapoport, Amos 1980. Human Aspects of Urban Form: Towards a Man Environment Approach to Urban Form and Design. New York: Pergammon Press.

Rapoport, Amnon. 1997. Order of play in strategically equivalent games in extensive form. International Journal of Game Theory, 26: 113-136.

Ronald, Arya. 2005. Nilai-nilai Arsitektur Rumah Tradisional Jawa. Yogyakarta: Gadjah Mada University Press. Sularto, Robi. 1978. "Rumah Orang Bali" dalam Indonesian Heritage Arsitektur. Jakarta: Grolier International.

Suryabrata, Sumadi. 2002. Metode Penelitian. Jakarta: Raja Grafindo Persada. 